\title{
Analisa Peningkatan Produksi Lem Dengan Metode Taguchi
}

\author{
Febi Rahmadianto ${ }^{1)}$, Eko Edy Susanto ${ }^{2)}$ Gerald A.P ${ }^{3)}$ \\ Institut Teknologi nasional Malang \\ Fakultas Teknologi Industri \\ Jalan Karanglo Km.2, Malang \\ E-mail : rahmadianto15@gmail.com ${ }^{1)}$
}

\begin{abstract}
ABSTRAKSI
Dalam hal ini, kami melakukan studi lapangan yang ada di lingkungan kelurahan Madyopuro. Kami melakukan pembuatan alat untuk pencampuran bahan bakar dan karet untuk pembuatan lem. Lem ini digunakan untuk perekat ban dalam vulkanisir ban. Dimana dalam ekonomi yang sekarang ini, daya beli masyarakat untuk membeli ban baru sangat tidak memungkinkan. Dengan adanya ban bekas yang divulkanisir menjadi ban baru sangat menolong dalam hal ekonomi. Dan usaha yang dilakukan masyarakat/pekerja, dapat mmbantu untuk meningkatkan perekonomian masyarakat yang terlibat langsung dalam pembuatan ban vulkanisir ini. Berjalannya waktu telah berdiri UKM yang memproduksi ban vulkanisir ini secara berkala, yaitu UKM DAMARU MANDIRI, milik Suhanaviryanto yang beralamatkan di jalan Wisnuwardana, Kelurahan Madyopuro, Malang

Metode pelaksanaan yang dilaksanakan pada kegiatan abdi masyarakat, berdasarkan mitra UKM terbagi kedalam beberapa permasalahan. Produksi langkah-langkah untuk menyelesaikan permasalahan :

Koordinasi dan diskusi dengan mitra tentang alat yang dibutuhkan, jadwal program. Desain, Desain mesin pengaduk lem, Koordinasi dan diskusi dengan tim teknisi alat, Uji coba mesin pengaduk lem, Penyerahkan alat ke mitra ukm. Pelatihan dan pendampingan dalam pengoperasian mesin pengaduk lem, Evaluasi penggunaan mesin pengaduk lem

Data analisis dengan metode Taguchi menunjukkan bahwa ketiga faktor yaitu Pengaduk secara Manual, Sirip terpisah dan Sirip Oval dapat di urutkan berdasarkan nilai ranking. Hasil tersebut menunjukkan bahwa Sirip Terpisah memiliki pengaruh terbesar terhadap Waktu Pengaduk Lem, diikuti dengan Sirip Oval, kemudian dengan Manual. Berdasarkan desain eksperimen Taguchi hasil grafik main Effect Plot for Means dengan pendekatan Smallest is the better, kondisi optimal dalam pengaduk lem adalah dengan menggunakan Sirip Terpisah.
\end{abstract}

Kata Kunci : Tenaga, Waktu, Peningkatan Hasil.

\section{PENDAHULUAN}

Kondisi Geografis Kelurahan Madyopuro merupakan kelurahan yang terletak di wilayah Kecamatan Kedungkandang, Kota Malang. Kelurahan ini terdiri dari 15 RW dan 108 RT. Secara administratif, Kelurahan Madyopuro dikelilingi oleh kelurahan lainnya yang ada di Kota Malang. Di sebelah utara, Kelurahan Madyopuro berbatasan langsung dengan Kelurahan Sawojajar, Kecamatan Kedungkandang. Sedangkan di sebelah timur, kelurahan ini berbatasan langsung dengan Kelurahan Cemorokandang, Kelurahan Kedungkandang. Di sebelah selatan, Kelurahan Madyopuro berbatasan dengan Kelurahan Lesanpuro, Kecamatan Kedungkandang. Lalu, di sebelah barat, kelurahan ini berbatasan dengan Kelurahan Sawojajar, Kecamatan Kedungkandang. Jarak Kelurahan Madyopuro dari pusat kota \pm 7 km,sedangkan dari kampus Institut Teknologi Nasional Malang (ITN) $\pm 15 \mathrm{~km}$.

Dalam hal ini, kami melakukan studi lapangan yang ada di lingkungan kelurahan Madyopuro. Kami melakukan pembuatan alat untuk pencampuran bahan bakar dan karet untuk pembuatan lem. Lem ini digunakan untuk perekat ban dalam vulkanisir ban. Dimana dalam ekonomi yang sekarang ini, daya beli masyarakat untuk membeli ban baru sangat tidak memungkinkan. Dengan adanya ban bekas yang divulkanisir menjadi ban baru sangat menolong dalam hal ekonomi. Dan usaha yang dilakukan masyarakat/pekerja, dapat mmbantu untuk meningkatkan perekonomian masyarakat yang terlibat langsung dalam pembuatan ban vulkanisir ini. Berjalannya waktu telah berdiri UKM yang memproduksi ban vulkanisir ini secara berkala, yaitu UKM DAMARU MANDIRI, milik Suhanaviryanto yang beralamatkan di jalan Wisnuwardana, Kelurahan Madyopuro, Malang. Tenaga Kerja yang ada di UKM ini sekitar 5 orang dengan upah tergantung hasil dari pembuatan ban.

Tingkat pendidikan tenaga kerja adalah lulusan SMP/sederajat. Sistem pembuatan ban vulkanisir ini masih sangat sederhana, dengan dilatih dan dididik secara bertahap oleh pemilik UKM. Pelatihan yang diterapkan pemilik sangat sederhana atas dasar pengetahuan dan ketrampilan seadanya.

Dengan adanya hambatan yang dialami pemilik, maka kami mengadakan studi lapangan dan merancang untuk melaksanakan abdi masyarakat. 


\section{METODE PENELITIAN}

Metode pelaksanaan yang dilaksanakan pada kegiatan abdi masyarakat, berdasarkan mitra UKM terbagi kedalam beberapa permasalahan. Di bidang Produksi langkah-langkah untuk menyelesaikan permasalahan :

1. Koordinasi dan diskusi dengan mitra tentang alat yang dibutuhkan, jadwal program. Desain,

2. Desain mesin pengaduk lem

3. Koordinasi dan diskusi dengan tim teknisi alat,

4. Uji coba mesin pengaduk lem

5. Penyerahkan alat ke mitra ukm

6. Pelatihan dan pendampingan dalam pengoperasian mesin pengaduk lem

7. Evaluasi penggunaan mesin pengaduk lem

\section{PERMASALAHAN MITRA}

Terhadap kondisi yang dialami pemilik ada berbagai macam, salah satunya proses pembuatan lem yang masih manual. Hal ini dilihat dari usaha yang dilakukan para pekerja dalam pembuatan lem sangat terbatas oleh tenaga dan waktu. Dengan cara manual dalam pembuatan lem, ukm ini dapat menghasilkan 30 ban per hari dari 8 jam bekerja. Maka dari itu, kami akan membuatkan alat sederhana, untuk mempermudah kerja para pekerja dan meningkatkan hasil produksi ban vulkanisir.

\section{Justifikasi Prioritas Masalah yang Disepakati Mitra untuk Diselesaikan}

Dari permasalahan yang telah diuraikan diatas, pelaku usaha mengharapkan bantuan untuk meningkatkan kinerja baik waktu, kualitas dan kuantitas hasil usahanya. Permasalahan yang akan dipecahkan adalah

1. Peningkatan waktu pembuatan lem,

2. Peningkatan kinerja tenaga kerja,

3. Peningkatan produksi.

4. Kerapian dalam menggulung plastik.

\section{SOLUSI YANG DITAWARKAN}

Dari analisa yang kami justifikasikan dengan mitra, disepakati untuk diselesaikan beberapa solusi yang ditawarkan yaitu perancangan dan pembuatan alat pencampur lem guna peningkatan effisiensi waktu serta kualitas hasil pencampur.

\section{HASIL DAN PEMBAHASAN}

\begin{tabular}{|c|c|c|c|c|c|c|}
\hline No & Manual & $\begin{array}{c}\text { Pisau } \\
\text { Sirip } \\
\text { Terpisah }\end{array}$ & $\begin{array}{c}\text { Pisau } \\
\text { Oval }\end{array}$ & Uji 1 & Uji 2 & Uji 3 \\
\hline 1 & 1 & 1 & 1 & 234 & 215 & 231 \\
\hline 2 & 1 & 2 & 2 & 211 & 209 & 201 \\
\hline 3 & 1 & 3 & 3 & 190 & 187 & 194 \\
\hline 4 & 2 & 1 & 2 & 187 & 185 & 191 \\
\hline 5 & 2 & 2 & 3 & 205 & 203 & 209 \\
\hline 6 & 2 & 3 & 1 & 203 & 201 & 207 \\
\hline 7 & 3 & 1 & 3 & 204 & 202 & 208 \\
\hline 8 & 3 & 2 & 1 & 215 & 213 & 219 \\
\hline 9 & 3 & 3 & 2 & 235 & 233 & 239 \\
\hline
\end{tabular}




\section{Hasil Pengujian Taguchi Method}

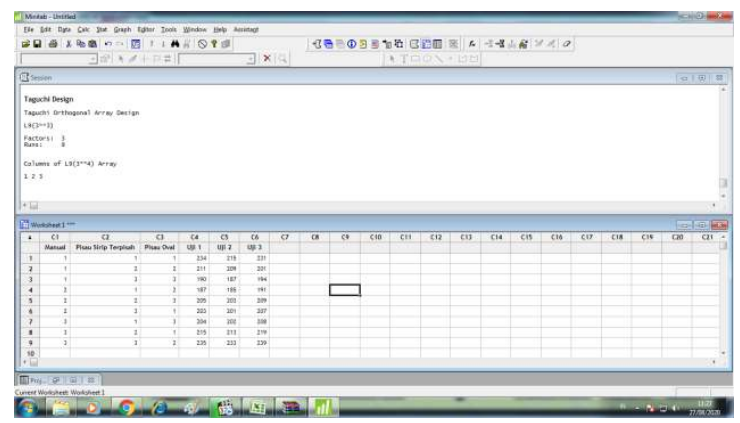

27/08/2020 11:23:20

Welcome to Minitab, press F1 for help.

\section{Taguchi Design}

Taguchi Orthogonal Array Design
L9 $(3 * 3)$

$\begin{array}{ll}\text { Factors: } & 3 \\ \text { Runs: } & 9\end{array}$

Columns of $\mathrm{L} 9(3 * * 4)$ Array

123

Taguchi Analysis: Uji 1; Uji 2; Uji 3 versus Manual; Pisau Sirip ; Pisau Oval

Response Table for Signal to Noise Ratios

smaller is better

$\begin{array}{lrrr}\text { Leve1 } & \text { Manua1 } & \begin{array}{r}\text { Pisau Sirip } \\ \text { Terpisah }\end{array} & \text { Pisau ova1 } \\ 1 & -46,34 & -46,27 & -46,66 \\ 2 & -45,97 & -46,42 & -46,41 \\ 3 & -46,78 & -46,41 & -46,03 \\ \text { De1ta } & 0,81 & 0,15 & 0,63 \\ \text { Rank } & 1 & 3 & 2\end{array}$

Response Table for Means

$\begin{array}{lrrr} & & \text { Pisau Sirip } & \text { Pisau } \\ \text { Leve1 } & \text { Manual } & \text { Terpisah } & \text { Oval } \\ 1 & 208,0 & 206,3 & 215,3 \\ 2 & 199,0 & 209,4 & 210,1 \\ 3 & 218,7 & 209,9 & 200,2 \\ \text { De1ta } & 19,7 & 3,6 & 15,1 \\ \text { Rank } & 1 & 3 & 2\end{array}$

Response Table for standard Deviations

Pisau Sirip Pisau

Level Manual Terpisah oval

$1 \quad 6,339 \quad 5,441 \quad 5,441$

$2 \quad 3,055 \quad 3,801 \quad 3,801$

$3 \quad 3,055 \quad 3,207 \quad 3,207$

De1ta $3,284 \quad 2,234 \quad 2,234$

$\begin{array}{rrrr}\text { Rank } & 1 & 2,5 & 2,5\end{array}$ 
Febi Rahmadianto , Eko Edy Susanto, Gerald A.P
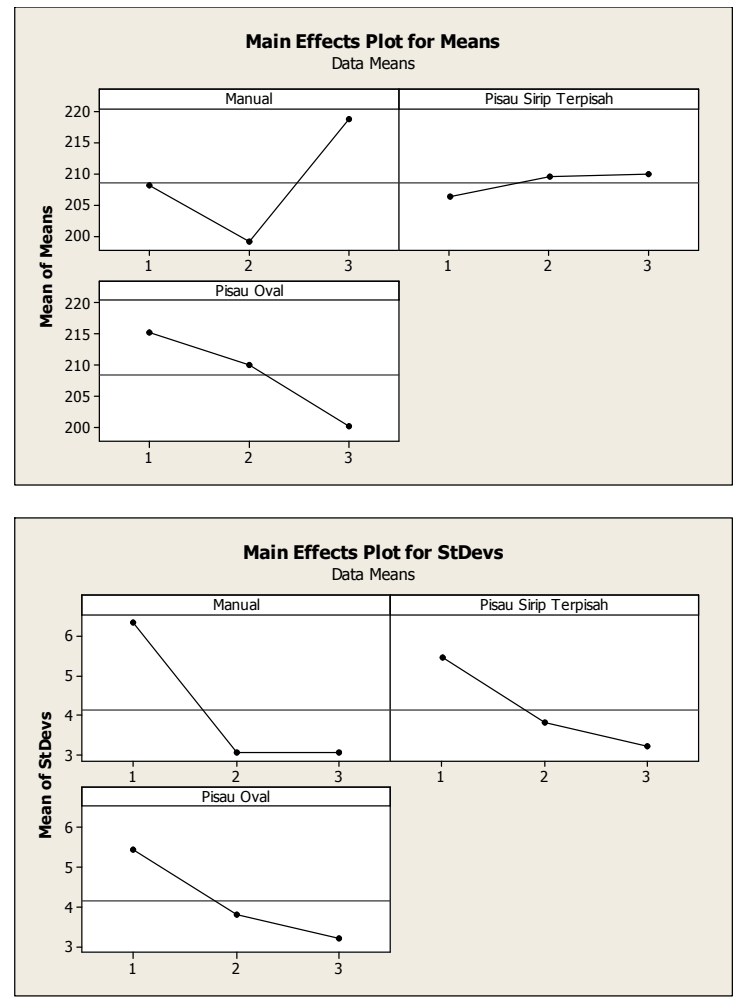

\section{PEMBAHASAN}

Data analisis dengan metode Taguchi menunjukkan bahwa ketiga faktor yaitu Pengaduk secara Manual, Sirip terpisah dan Sirip Oval dapat di urutkan berdasarkan nilai ranking. Hasil tersebut menunjukkan bahwa Sirip Terpisah memiliki pengaruh terbesar terhadap Waktu Pengaduk Lem, diikuti dengan Sirip Oval, kemudian dengan Manual. Berdasarkan desain eksperimen Taguchi hasil grafik main Effect Plot for Means dengan pendekatan Smallest is the better, kondisi optimal dalam pengaduk lem adalah dengan menggunakan Sirip Terpisah.

\section{KESIMPULAN}

1. Dengan dilakukannya program berkala untuk pengoptimalan dari mesin pengaduk lem dan perawatan dari mesin tersebut.

2. Pisau Pengaduk Lem yang optimal menggunakan pisau terpisah dengan waktu tercepat dalam menghancurkan bahan lem.

\section{SARAN}

1. Tingkat pemahaman dalam pengoperasian mesin perlu ditingkatkan kembali dikarenakan SDM yang ada masih rendah penangkapan cara pengoperasiannya.

2. Program Pelatihan dapat dilakukan secara berkala

\section{DAFTAR PUSTAKA}

[1] [1] Panduan Pelaksanaan Penelitian dan Pengabdian Kepada Masyarakat Edisi XII Tahun 2018

[2] [2] F.Rahmadianto 2019. Penerapan Keselamaan Kerja Pada Bengkel Sepeda Motor Di Kelurahan Polowijen Kecamatan Blimbing Malang. Jurnal Flywheel. Institut Teknologi Nasional. Malang.

[3] [3] F.Rahmadianto 2018. Perencanaan Pemeliharaan Pompa Hidram Di Desa Ngadireso, Poncokusumo-Malang. Jurnal Aplikasi Dan Inovasi Ipteks" Soliditas"(J-Solid). Universitas Widyagama. Malang. 